\title{
Accounting
}

\section{Conceptualizing the effects of corporate tax rate differentials on transfer pricing activities of FDI enterprises in Vietnam}

\author{
Hong Nhat Nguyen ${ }^{a *}$, Jacquline Tham ${ }^{a}$, Ali Khatibi ${ }^{a}$ and S. M. Ferdous Azama
}

\begin{tabular}{l}
${ }^{a}$ Management \& Science University \\
\hline C H R O N I C L E \\
\hline Article history: \\
Received November 202019 \\
Received in revised format \\
December 272019 \\
Accepted February 192020 \\
Available online \\
February 192020 \\
\hline Keywords: \\
Vietnam \\
Corporate tax rate differentials \\
FDI \\
Transfer pricing
\end{tabular}

\section{Introduction}

In a global economy, transfer pricing has been long an issue of a particular intention of not only the governments but also economists, investors or CEO, according to Akpojevwa (2014), Agarwal (2016), Hung (2017), Nguyen et al. (2019) and Nguyen et al. (2020). As globalisation broadening, foreign direct investment (FDI) enterprises start to increase their international investment and trade, transfer pricing (TP) becomes more matured with varieties of methods (Agarwal, 2016). Under this context, many governments from developed and developing countries pay keen attention to have control over transfer pricing in FDI enterprises (Akpojevwa, 2014; Dillman et al., 2014). Over the past years, the studies of TP for tax avoidance carried out by FDI enterprises have always been highlighted at relevant conferences and meetings around the world, including the Summit of G8, G20 or global forums on tax issues of Organization of Economic and Cooperation Development. Transfer pricing takes special attention from senior government officials to experts, economists, managers as well as the economic institutions or business communities as researchers seem to see it as a challenge to both developing and developed countries (Borkowaki, 1997b; Thang, 2015; Thu, 2018). In several developed countries, the governments have implemented several methods, including tariff and non-tariff barriers to deal with this phenomenon, which have brought significant results. Specifically, the G20 member countries passed the BEPS package of "base erosion and profit shifting" with 15 action plans since 2015. The so call BEPS

* Corresponding author. Tel: +84-908850999

E-mail address: nhnhat07@gmail.com (H. N. Nguyen)

\begin{abstract}
The purpose of this paper is to evaluate the differentials effects of the tax rate on transfer pricing activities in foreign direct investment enterprises in Vietnam. The study then suggests further research on the determinants over transfer pricing activities of these enterprises to have better solutions in
dealing with transfer mispricing in Vietnam. A quantitative research method involving selfadministered closed-ended questionnaires were extended to Managing Directors/Chief Executive Officers, Tax Managers/ Directors, Chief Finance Officers or Heads of Finance from foreign direct investment enterprises in Vietnam. Findings indicate a strong relationship between corporate tax rate differentials and the transfer pricing activities in foreign direct investment enterprises in Vietnam. The

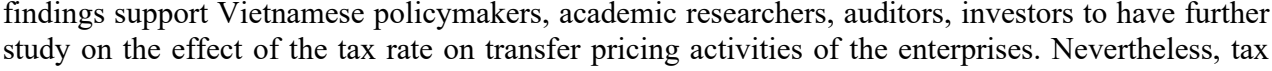
officials and accounting representatives can have in-depth knowledge with regards to transfer pricing activities which the outcome of this study aspires as guidance for better understanding the aspects of transfer pricing while doing business in Vietnam.
\end{abstract}


package aims at developing solutions to prevent and to minimise the profit shifting, tax avoidance of multinational corporations. Located in South East Asia, Vietnam is a developing country of which the Government has increasingly considered FDI as an essential resource for national development. More than thirty years since the Law on Foreign Investment of Vietnam came into effect in 1987, FDI into Vietnam has been increasing in terms of registered capital and implemented capital. According to the statistic of Vietnam Ministry of Planning and Investment (2018), by the end of 2018, Vietnam has attracted more than 27,300 FDI projects with the total registered capital of approximately 340 billion US dollars. With their business, manufacturing and trading, politicians, economists, and bankers considered FDI as a source of growth that brings about finance, expertise, knowhow, technology transfer, and also the markets. FDI enterprises also create many advantages, among which include providing jobs, improving the quality of human resources, integrating profoundly and broadly into international trade. In another aspect, besides ethical impacts, FDI enterprises also generate some remaining and disadvantages. Among these disadvantages is the drawback of TP abuse to avoid taxes, transferring profits to the country of origin (Hung, 2017). Aiming at maximising profits in business, TP has been long used in multinational enterprises with cross-national related transactions, or among parent companies and their branches in different countries. With the varieties in tax systems, mainly corporate income tax, these multinational companies (MNCs) will apply different methods of pricing, technology - intellectual and resources transfer, to allocate and reallocate the profits among companies of one group. In parallel with globalisation, FDI capital and resources flow can quickly go from this country to others, and TP abuse develops in different types and methods. This situation can make the tax officials hard to evaluate the real business situation of the companies, whether the loss is real or they make profits but reporting of loss. As TP activities in FDI enterprises in Vietnam is getting more complicated, the government records of many FDI enterprises reporting of profit loss (but still enlarge their business). Therefore, this paper is carried out to identify the factors that corporate tax rate differentials among countries effect on TP activities of FDI enterprises in Vietnam. The research question is carried to know: What is the relationship between corporate tax rate differentials among countries and TP activities in FDI enterprises in Vietnam. The need for understanding whether corporate tax rate differentials have impacts on TP activities of FDI enterprises is critical to have a suitable program in dealing with the TP abuse. Findings derive through this paper will provide a more precise picture of the TP situation in Vietnam for a better tax rate in the future. In term of academia, the study on the impact of corporate tax rate differentials on TP activities in FDI enterprises can be the base for other researches in approaching TP and TP abuse, under the context of complex TP activities of multinational corporations in this open economy.

\section{Review of Literature}

The transfer pricing activities that enterprises are carrying out and the anti-transfer pricing activities being carried out by the governments have always been going opposite site. Whenever the governments deploy any new method or solution to manage transfer pricing activities, the enterprises will promptly find other ways to set transfer price, because the enterprises' final objective is always profit. Many types of research have shown that transfer pricing activities pose several negative impacts on the host countries, namely tax losses, import turnover growth, and business competition inequality. This is the main reason that makes public governance as well as the business community to take transfer price and transfer pricing as a hot issue of special attention. We can find many policymakers, researchers, economists, specialists and businesses pay particular interest in this issue. In international and in Vietnam researchers, there have been a lot of researches and articles relating to transfer price and transfer pricing with different point of views, methodology, objectives, in both theory and reality, to clarify the definition, nature, characteristics, method of transfer pricing; impacts of transfer pricing; or solutions to control transfer pricing and transfer mispricing. To understand, firstly, the author finds the definition of transfer price and transfer pricing. According to Organization of Economic and Cooperation Development, transfer price is the price when members of transnational groups of companies carry out the transactions with each other (for instance the sales of raw materials or technology transferring), this transfer price is showed in the accounts of these enterprises and used for the calculation of official accounting and profits. This transfer prices that set by multinational corporations will affect the amount of profits that they report in the country that they have their business. Several researchers in Vietnam including Nguyen (2018) and Do (2014) both agree that "transfer price" is a universal term that shows how the price is set in internal transactions among member companies of one multinational company. That is the price that these multinational companies set for the import and export activities of their member companies. However, while foreign researchers study on transfer price as an independent term, as the authors, as mentioned earlier, but "transfer price" in a transparent relationship with a transaction, under these researches, Vietnamese authors state that "transfer price" in affiliated transactions is set higher or lower to fulfil the objectives of enterprises, therefore to minimise the tax payment, and finally to maximise the benefit. As a result, setting transfer price is the cause leading to transfer pricing and pose adverse effects on the socio-economic condition of the host nations. According to many foreign researchers such as Agarwal (2016), United Nations (2013), Borkowski (1997), Kayfetz \& Helzel (1996), Lecraw (1985), Stewart (1977), or Lall (1973), when the companies have affiliated relationship, they carry out their internal transaction with an internal transfer price that is not the market price (this price can be higher or lower than the market price), in order to change the loss and profits of member companies, in order to reduce the tax payment lower than when transaction with the market price, then this activity is called transfer mispricing or transfer pricing manipulation. According to Patroi (2013), transfer prices are the "end-point of ingenuity in the area of tax legislation", because transfer prices are the link between tax regulations existing in different national and international markets. 
Foreign researches and domestic researches have shown that the purpose of any companies when applying transfer mispricing or transfer pricing manipulation is to maximise the profits by minimising corporate income tax payment, to keep their targets or to analyse the management evaluation. This can be interpreted that these companies will reallocate profits from countries with a high tax rate to countries with low tax rate or tax heaven to reduce total tax payment in all countries of the multinational corporations. This will lead to the situation when the tax rate differentials among countries will have an impact on the transfer pricing activities of foreign direct investment enterprises in Vietnam. Agarwal (2016) in his research also agreed with the point that stated by Organization of Economic and Cooperation Development that: by changing the transfer prices among different transactions, one multinational corporation will reflect its revenue under different types in one country to minimise the tax payment at this country; and by changing internal transfer price in internal transactions, MNCs can transfer before tax profit from one country to another country to maximise after-tax profit. The author also has a study on the term of foreign direct investment enterprises to define it clearly. According to Organization of Economic and Cooperation Development, a Foreign Direct Investment enterprise is an enterprise locating in one country and in which the investor living in another country owns, either directly or indirectly, with at least $10 \%$ of its voting power for an incorporated enterprise or an equivalent for an unincorporated one. The ownership of $10 \%$ voting power shows the existence of a direct investment relationship between the direct investor and the direct investment enterprise. Furthermore, the ownership of at least $10 \%$ of the voting power of the enterprise is supposed to be necessary for the investor to have sufficient influence and compelling voice in its business management. In the Investment Law of Vietnam (2014), FDI enterprises are defined as economic organisations that meet the conditions and shall carry out investment procedures according to regulations applicable to foreign investors that having $51 \%$ or more of the charter capital by foreign individuals or organisations. For the study of this paper, foreign direct investment enterprises are chosen according to this definition of the Investment Law of Vietnam and these enterprises present in Vietnam. Every year, the General Department of Statistics of Vietnam will release the statistics include the number of foreign direct investment enterprises in Vietnam, state what countries or territories that the investors of these enterprises come from and therefore the author can have a look at the countries when they start their investment into Vietnam. The economic theory suggests that foreign direct investment enterprises always want to maximise total after-tax profits by allocating revenues to low-tax and deductions to high-tax jurisdictions, according to Horst (1971). Therefore, transfer mispricing is widely believed to be the main reason for the activities of income shifting. The author also finds a significant source of theoretical literature showing that transfer pricing responses to income tax differentials (Horst, 1971; Halperin and Srinidhi, 1987; Eden, 1998). The tax rate gap among countries is a reason that related parties involving in transfer pricing (Duong, 2018). Those countries uniquely named as tax haven have always taken particular intention from FDI enterprises as they do their business in a foreign country. According to the research of Liu, Tim, and Guo (2017), companies often manipulate the transfer prices to shift profits to lower-taxed destinations and tax-motivated transfer pricing abuse is prevalent in those nations and territories that are not tax havens, and the corporate tax rates are often at the low to medium level. Tax can be used to explain why investors have to move from their original countries to other countries, doing business and setting up branches, companies in other countries and territories. One possible reason for this may be the fact that the tax difference among countries has been creating strong incentives for multinational enterprises to reallocate their divisional accounting profits by manipulating transfer prices.

\section{Research Methodology}

The authors applied the research onion provided by Saunders et al. (2016) to do this research. The research onion here is a bounded framework with six layers: research philosophies; research approaches; research strategies; research methods; the time to carry out the research and academic study; and the process of data collection and data analysis to achieve critical findings. Based on the literature review, Hypotheses were developed, whereby, there is a relationship between corporate tax rate differentials and TP activities of FDI enterprises in Vietnam. In this hypothesis, "corporate tax rate differentials" is the independent variable, "foreign direct investment enterprises" is mediating variable and "transfer pricing activities" is the dependent variable.

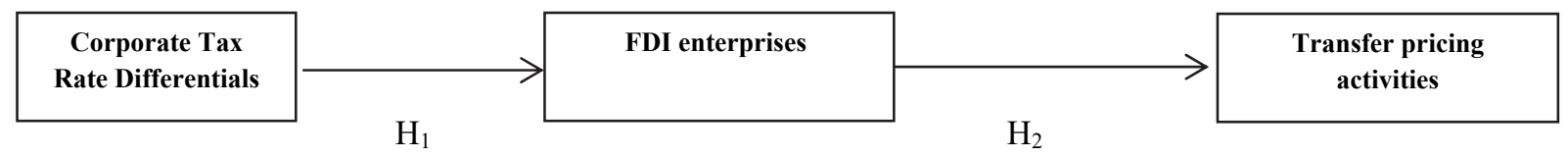

Fig. 1. Hypotheses

The hypothesis is developed. Hypothesis 1: there is a relationship between corporate tax rate differentials and foreign direct investment enterprises and Hypothesis 2 is that foreign direct investment enterprises have a relationship with transfer pricing activities. This focuses on foreign direct investment enterprises, not domestic enterprises, therefore the authors set the hypothesis that these foreign direct investment enterprises pose an impact on transfer pricing activities of enterprises. Approaching the first layer, the authors have a choice among research philosophies. The four main research philosophies include positivism, constructionism, critical realism, and pragmatism (Sekaran \& Bougie, 2013). This study is based on primary data collected from a significant sample size, which is supported by positivism philosophy. The second layer of research opinion relates to the research approach, which includes deductive and inductive, according to Saunders et al. (2016). To study this paper, the author has selected a deductive approach due to several reasons. The paper is to research the activities behaviour of Vietnamese FDI 
enterprises, and there is a large number of empirical evidences that relate to this study's topic. In the context of TP activities, deductive approach is more appropriate to be applied as Armat et al. (2018) affirmed that deductive approach is better used when some views or previous findings and theories are available for target social phenomenon. Another essential reason to choose this research approach is that deductive is suitable for positivism philosophy (Bilau et al., 2018), with a large sample size (Saunders et al., 2016). This research strategy is based on a deductive approach (Saunders et al., 2016) in which primary data were collected to verify the hypotheses of this study. Secondly, this research strategy helps to analyse the activities behaviour of FDI enterprises towards TP. Also, according to Saunders et al. (2016) survey strategy is often lower cost and shorter time in comparison to the others, which is last but not least reason for choosing this research strategy. The quantitative research method is used, and statistical analyses were performed to generate findings for this study (Saunders et al., 2016) based on structured, Likert scale questionnaires which were adapted and developed for this study (Biggam, 2015). The evaluation of causal linkages among variables was performed (Saunders et al., 2016; Easterby-Smith et al., 2015).

For this study, secondary data is collected from published statistics and official reports in Vietnam and worldwide that relate to the issue. Moreover, given to the understandings of primary data, the authors decided to collect data from questionnaires with the respondents - which is a useful data collection instrument in case of quantitative research is applied (Walliman, 2017). According to Hanlon and Larget (2011), the population of this paper refers to the FDI enterprises locating in Vietnam that having controlled transactions with its affiliated partners. The author also collects this information in the questionnaire, and when the enterprise does not meet this criterion, it will be deleted from the dataset. Expected respondents of these enterprises will be Chief Executive Officers or Managing Directors, Tax Managers, Tax Directors, Chief Finance Officers, Heads of Finance or at an equivalent position from the enterprises. Nevertheless, by the end of 2018, Vietnam has attracted 27,300 FDI enterprises (Ministry of Planning and Investment, 2018). In terms of population, the probability sampling method was used for the study as this helps the researcher to control sampling biases and systematic errors. The main sub-technique of probability sampling that is applied in this study is systematic sampling with the benefit of very easy to conduct, less cost and convenient in case of a large population (Etikan \& Bala, 2017). Having the technique for sampling, with a high population, two sample sizes are generated accordingly. The original sample size is decided for the pilot test of the survey, and the second one is chosen for the official survey. The sample size for the pilot test of the survey is generally from 25 to 100 , or it consumes $10 \%$ of the sample size of the official survey (Memon et al., 2017). And the researcher targets at the sample size of 379 respondents, a good number according to Krejcie and Morgan (1970), Cohen (1969). However, in order to collect enough 379 respondents, 500 questionnaires were delivered based on a $70 \%$ response rate

Email survey with self-administered questionnaires was used in this study. The motivation of using email survey is that corporate internet usage rate in Vietnam is $100 \%$ of the total population. The corporate tax rate differentials are measured with four items. Transfer pricing activities has three measurement items, and foreign direct enterprise has three measurement items. In terms of corporate tax rate differential, the author measure to know the response in the same corporate income tax among countries will minimize transfer pricing manipulation of enterprises; Vietnamese corporate income tax rate that the company has to pay annually is high for the company; Transfer pricing activities among related parties can help reduce total global tax liability, and Corporate income tax incentive affects TP activities. In terms of transfer pricing activities, the author measures the answers of despondences in following questions: Transfer pricing activities are carried out to maximize the profits; Transfer pricing matters are discussed in board meetings of FDI enterprises very frequently; parent companies often require transfer pricing from foreign countries. In terms of foreign direct investment enterprises, the questions included: TP activities among related parties of FDI enterprise can increase global consistency of approach; Corporate tax rate of different countries affect the transfer pricing activities among these countries; TP activities among associated partners are a method that FDI enterprises use to operate its business. The research questions are self-deployed; some of them are taken from Deloitte (2016) and Liu (2017). Each item in the questionnaire table above is evaluated using a specific scale. According to Wadgave and Khairnar (2016), Likert scale is a psychometric response scale that is used to get the responses of respondents when they receive a set of questions or statements.

\section{Table 2}

Questionnaires

\begin{tabular}{|c|c|c|c|c|c|}
\hline \multicolumn{6}{|l|}{ Corporate Tax Rate Differentials } \\
\hline 1. The same corporate income tax among countries will minimize transfer pricing manipulation of enterprises & 1 & 2 & 3 & 4 & 5 \\
\hline 2. Vietnamese corporate income tax rate that the company has to pay annually is high for the company & 1 & 2 & 3 & 4 & 5 \\
\hline 3. Transfer pricing activities among related parties can help reduce total global tax liability & 1 & 2 & 3 & 4 & 5 \\
\hline 4. Corporate income tax incentive has effect on TP activities & 1 & 2 & 3 & 4 & 5 \\
\hline \multicolumn{6}{|l|}{$\begin{array}{ll} & \text { Transfer Pricing activities } \\
\end{array}$} \\
\hline 1. Transfer pricing activities are carried out to maximized the profits & 1 & 2 & 3 & 4 & 5 \\
\hline 2. Transfer pricing matters are discussed in board meetings of FDI enterprises very frequently & 1 & 2 & 3 & 4 & 5 \\
\hline 3. Transfer pricing is often required by parent companies from foreign countries. & 1 & 2 & 3 & 4 & 5 \\
\hline \multicolumn{6}{|l|}{ FDI enterprises } \\
\hline 1. TP activities among related parties of FDI enterprise can increase global consistency of approach & 1 & 2 & 3 & 4 & 5 \\
\hline 2. Corporate tax rate of different countries have effect on the transfer pricing activities among these countries & 1 & 2 & 3 & 4 & 5 \\
\hline 3. TP activities among associated partners are a method that FDI enterprises use to operate its business. & 1 & 2 & 3 & 4 & 5 \\
\hline
\end{tabular}


Likert scale is often categorized through three-point scales, five-point scales or seven-point scales and Likert scale can help the author to examine how the respondents to rate whether they agree or disagree with a statement. It is also needed to pay attention that Likert scale ranks the respondents' answers from low to high with the negative pole is on the left-hand side, and the positive pole is on the right-hand side, according to Hartley (2013). In this study, five points Likert scale is utilized to collect the respondents' attitudes with 1 as strongly disagree, 2 as disagree, 3 as neutral, 4 as agree, and 5 as strongly agree. The questionnaire is displayed in Table 2. Statistical Package for the Social Sciences (the software owned by IBM with version SPSS 16.0) and AMOS. Finally, ethical considerations are also at concerns of the author while carrying out survey involving the participation of respondents according to Saunders et al. (2016).

\section{Empirical Analysis}

The expected population of 379 respondents is used for official survey, a thorough analysis of the study. For this paper, 150 respondents have filled up with the questionnaires. The researcher applies SPSS software to analyse: descriptive statistics, reliability test, and exploratory factor analysis. AMOS software is then used to analyse the research model and hypothesis testing.

\subsection{Demographic of the enterprises}

The demographic figures of FDI enterprises are shown in Table 3. These include the operation time, business field, and the department in charge of TP of the enterprises. It also includes whether the enterprise has an internal TP policy or not.

Table 3

Categories of FDI enterprises

\begin{tabular}{|c|c|c|c|}
\hline Variable & Characteristics & Frequency & Percent \\
\hline \multirow[t]{5}{*}{ Annual average turnover } & More than 200 billion VN dongs & 42 & 28 \\
\hline & $100-200$ billion $\mathrm{VN}$ dongs & 67 & 44.7 \\
\hline & 50 - less than 100 billion $\mathrm{VN}$ dongs & 36 & 24 \\
\hline & Less than 50 billion VN dongs & 5 & 3.3 \\
\hline & Total & 150 & 100 \\
\hline \multirow[t]{4}{*}{ Average profit rate } & $>0$ & 37 & 24.7 \\
\hline & $=0$ & 50 & 33.3 \\
\hline & $<0$ & 63 & 42 \\
\hline & Total & 150 & 100 \\
\hline \multirow{3}{*}{$\begin{array}{l}\text { Controlled transactions with parent company/ } \\
\text { associated partners }\end{array}$} & Yes & 121 & 80.7 \\
\hline & No & 29 & 19.3 \\
\hline & Total & 150 & 100 \\
\hline \multirow[t]{4}{*}{ Number of controlled transactions } & No transaction & 29 & 19.3 \\
\hline & 1 - 3 transactions & 4 & 2.7 \\
\hline & $>3$ transactions & 117 & 78 \\
\hline & Total & 150 & 100 \\
\hline
\end{tabular}

Currently, the annual average turnover of the FDI enterprises is categorized into $>200$ billion VN dongs; $100-200$ billion VN dongs; $50-<100$ billion VN dongs; and $<50$ billion VN dongs. The survey shows that most of the enterprises had the annual average turnover of 100 to 200 billion Vietnam dongs (67 respondents, 44.7\%), followed by more than 200 billion VN dongs (42 respondents, 28\%). The number of enterprises with a turnover of 50 to 100 billion VN dongs is 36 respondents, $24 \%$. Furthermore, only five respondents (3.3\%) are from enterprises with turnover smaller than 50 billion VN dongs per year. Furthermore, the average profit rate of these enterprises mostly profit-lost with 63 respondents, $42 \%$ have the figure of less than Zero. 33.3\% of respondents (50 enterprises) said they have no profit (profit rate of 0 ) and the remaining of 37 respondents $(24.7 \%)$ confirmed they have profit. Getting to know whether the enterprises have controlled transactions with their parent company/associated partners or not, only 29 respondents $(19.3 \%)$ pointed out that they have no associated transactions. Meanwhile, 121 respondents $(80.7 \%)$ said they have controlled transactions. Therefore, 29 respondents (19.3\%) said they had no affiliated transactions. Many of the respondents said they had more than three transactions every year (117 respondents, $78 \%$ ), while only four respondents $(2.7 \%)$ confirmed they had only $1-3$ controlled transactions per year.

\subsection{Descriptive statistics}

Descriptive statistics express the mean value of each item in the questionnaire. The result obtained from the survey is presented in Table 4. In terms of Corporate tax rate differentials, it includes four items being coded into from TRD1 to TRD4. Mean values of TRD1, TRD2, TRD3, and TRD4 are 3.56, 3.73, 3.49 and 3.70, respectively. It is emphasized that three items of TRD1, TRD2, and TRD4 have mean value more than 3.5 and TRD3 has to mean value less than 3.5 and higher than 2.5. Thus, it is concluded that the respondents agree with the statement that: the same corporate income tax among countries will minimize transfer pricing manipulation of enterprises; Vietnamese corporate income tax rate that the company has to pay annually is high for the company, and corporate income tax incentive has an effect on TP activities. Otherwise, they are neither agreeing nor disagreeing with the statements that transfer pricing activities among related parties can help reduce total global tax liability. For FDI enterprises, 
the author coded into FDI1, FDI2, and FDI3. The mean values of FDI1, FDI2, and FDI3 are 3.90, 3.78 and 4.03, respectively. This figure shows that the respondents agree with all the statement items of this variable. The respondents agree that transfer pricing activities are carried out to maximize the profits; transfer pricing matters are discussed in board meetings of FDI enterprises very frequently, and transfer pricing is often required by parent companies from foreign countries. For the transfer pricing activities, the author coded into TP1, TP2, and TP3. The mean values of TP1, TP2, and TP3 are 3.24, 3.58 and 3.31. Item TP1 and TP3 have a mean value of less than 3.5 and higher than 2.5. Thus, it is concluded that they are neither agreeing nor disagreeing with all the statements TP activities among related parties of FDI enterprise can increase global consistency of approach, and TP activities among associated partners are a method that FDI enterprises use to operate its business. TP2 has the mean value of more than 3.5, means that the respondents agree with the statement that: the corporate tax rate of different countries affect the transfer pricing activities among these countries.

\section{Table 4}

Descriptive Statistics

\begin{tabular}{|c|c|c|c|c|c|}
\hline & $\mathrm{N}$ & Minimum & Maximum & Mean & Std. Deviation \\
\hline TRD1 & 150 & 1 & 5 & 3.56 & 0.596 \\
\hline TRD2 & 150 & 1 & 5 & 3.73 & 0.723 \\
\hline TRD3 & 150 & 1 & 5 & 3.49 & 0.599 \\
\hline TRD4 & 150 & 1 & 5 & 3.70 & 0.758 \\
\hline FDI1 & 150 & 1 & 5 & 3.90 & 0.702 \\
\hline FDI2 & 150 & 1 & 5 & 3.78 & 0.834 \\
\hline FDI3 & 150 & 1 & 5 & 4.03 & 0.750 \\
\hline TP1 & 150 & 1 & 5 & 3.24 & 0.939 \\
\hline TP2 & 150 & 1 & 5 & 3.58 & 0.861 \\
\hline TP3 & 150 & 1 & 5 & 3.31 & 0.891 \\
\hline Valid N (listwise) & 150 & & & & \\
\hline
\end{tabular}

\subsection{Reliability test analysis}

The author carries out a reliability test to check the internal consistency among items of one variable. Cronbach's alpha, Corrected item-total correlation, and Cronbach's alpha if item deleted are calculated. Cronbach's alpha is used to test of the inter-item consistency, according to (Sekaran and Bougie, 2013), Cronbach's Alpha is utilized to know the average intercorrelation among the items used to measure the concepts. The closer Cronbach's Alpha is to 1, the higher the internal consistency reliability, the range of 0.70 is considered to be acceptable if the figure is 0.80 that will be good and excellent for 0.90 . On the other hand, if the range is low under 0.60 , the variable will be considered not suitable for the study and should find the item that affects the measurement, to see whether should remove it to improve the inter-item consistency. Besides, when deleting one item, the new Cronbach's alpha must be smaller than the original value before this item is deleted. The result is presented in Table 5. Cronbach's alpha values for corporate tax rate differentials, foreign direct investment enterprises and transfer pricing activities is calculated at $0.762,0.754$ and 0.849 respectively, and all the figures are higher than 0.70 . The corrected item-total correlation of the reliability test shows that all items have the value of more than 0.30 . The last figure, when one item is deleted, the new Cronbach alpha is lower than the original one. Therefore, it can be concluded that internal consistency among items of a factor is satisfied. Furthermore, none of the input is deleted because the reliability test is accepted. The author then continues to EFA analysis to get the result of the survey.

\section{Table 5}

Reliability test analysis

\begin{tabular}{|c|c|c|c|c|}
\hline Factor & Code & Cronbach's Alpha & Corrected Item-Total Correlation & Cronbach's Alpha if Item Deleted \\
\hline \multirow[t]{4}{*}{ Corporate Tax Rate Differentials } & TRD1 & \multirow[t]{4}{*}{0.762} & 0.632 & 0.674 \\
\hline & TRD2 & & 0.633 & 0.664 \\
\hline & TRD3 & & 0.544 & 0.716 \\
\hline & TRD4 & & 0.467 & 0.756 \\
\hline Foreign Direct Investment & FDI1 & \multirow[t]{3}{*}{0.754} & .638 & .617 \\
\hline \multirow{2}{*}{ Enterprises } & FDI2 & & .565 & .700 \\
\hline & FDI3 & & .557 & .700 \\
\hline \multirow[t]{3}{*}{ Transfer Pricing Activities } & TP1 & \multirow[t]{3}{*}{0.849} & .810 & .694 \\
\hline & TP2 & & .560 & .826 \\
\hline & TP3 & & .801 & .707 \\
\hline
\end{tabular}

\subsection{EFA Analysis}

EFA analysis is required to calculate KMO and Bartlett's test. The components of initial eigenvalues of more than 1.0 are accepted, and selected components must have cumulative \% variance of more than $50 \%$. Factor loading of each item is expected to be higher than 0.5 and Varimax is used as a rotation technique. The EFA analysis is conducted, and the result is presented in Table 6 as follows: 
EFA Analysis result after Varimax rotation

\begin{tabular}{|c|c|c|c|c|}
\hline \multicolumn{4}{|c|}{ KMO $=0.748 ;$ Bartlett's test $=638.290$, p-value $<0.001$} & \multirow{4}{*}{ Communalities } \\
\hline Component & 1 & 2 & 3 & \\
\hline Initial eigenvalues & 3.819 & 1.824 & 1.255 & \\
\hline$\%$ of variance & 38.186 & 18.244 & 12.547 & \\
\hline TRD1 & 0.854 & & & 0.746 \\
\hline TRD2 & 0.744 & & & 0.642 \\
\hline TRD3 & 0.753 & & & 0.612 \\
\hline TRD4 & 0.622 & & & 0.451 \\
\hline FDI1 & & & 0.829 & 0.741 \\
\hline FDI2 & & & 0.806 & 0.674 \\
\hline FDI3 & & & 0.682 & 0.652 \\
\hline TP1 & & 0.939 & & 0.900 \\
\hline TP2 & & 0.669 & & 0.594 \\
\hline TP3 & & 0.935 & & 0.886 \\
\hline
\end{tabular}

The obtained findings from KMO and Bartlett's test confirm that EFA is able to use for the data set of 150 respondents. KMO value is 0.748 , and it is higher than 0.5. At the meantime, Bartlett's test value is estimated at 638.290 and p-value less than 0.001. The result means that KMO and Bartlett's test satisfy the pre-test of EFA and the data analysis technique is suitable. There are three components which are extracted with initial eigenvalues of more than 1.0 and the cumulative \% variance explained by these components is higher than 50\%. Component 1 has an initial eigenvalue of 3.819, and it can be used to explain for $38.186 \%$ of the variance. Component 1 have all items of corporate tax rate differentials. The initial eigenvalue of component 2 is 1.824 , and it can be used to explain for $18.244 \%$ of the variance. Component 2 have all items of the transfer pricing activities. Component 3 has an initial eigenvalue of 1.255 , and it can be used to explain for $12.547 \%$ of the variance. Component 3 includes all items of foreign direct investment. The detail description of each component is shown further as follows: Component 1 includes all items of corporate tax rate differentials and factor loading values calculated for TRD1, TRD2, TRD3, and TRD4 are $0.854,0.744,0.753$ and 0.622 respectively. All factor loading values are higher than 0.5 . Component 2 includes all items of transfer pricing activities and factor loading values calculated for TP1, TP2 and TP3 are 0.939, 0.669 and 0.935 respectively. All factor loading values are higher than 0.5. Component 3 includes all items of the capacity of foreign direct investment enterprises and factor loading values calculated for FDI1, FDI2, and FDI3 are 0.829, 0.806 and 0.682 respectively. All factor loading values are higher than 0.5 .

\subsection{Evaluation of research model}

AMOS is used to evaluate research model. The output of the model fit in presented in Table 7. It is significant that Chi-square/df $(\mathrm{CMIN} / \mathrm{DF})$ is 1.445 , and it is lower than 5. CFI value is calculated at 0.983 and RMSEA is 0.055 , all justified with the benchmark. It can be concluded that the model is fitted with the dataset. Therefore, hypothesis testing will be analyzed in the next section.

\section{Table 7}

Research Model

\begin{tabular}{lll}
\hline Indicator & Benchmark & Result \\
\hline Chi-square/df & $<=5$ & 1.445 \\
CFI & $>0.9$ & 0.983 \\
RMSEA & $<=0.08$ & 0.055 \\
\hline
\end{tabular}

\subsection{Hypothesis testing}

The result of hypothesis testing is presented in Table 8 below:

Table 8

Hypothesis testing

\begin{tabular}{lcccccc}
\hline & Estimate & S.E. & C.R. & P-value & Hypothesis & Result \\
\hline FDI $\leftarrow$ TRG & 0.747 & 0.159 & 4.697 & $* * *$ & H1 & Supported \\
TP FDI & 0.502 & 0.147 & 3.421 & $* * *$ & H2 & Supported \\
\hline
\end{tabular}

$\mathrm{H}_{1}$ indicates that the corporate tax rate differentials have positive and significant effects on foreign direct investment enterprises. The coefficient is estimated at 0.747 , justified the benchmark of more than 0.2 . The p-value is less than 0.001 . Therefore, H1 is supported. $\mathrm{H} 2$ indicates that foreign direct investment enterprises have positively and significantly affected the transfer pricing activities. The coefficient is estimated at 0.502, higher than 0.2. The p-value is less than 0.001. Therefore, H2 is accepted. So, after all analysis and testing, the result shows that hypothesis 1: there is a relationship between corporate tax rate differentials 
and foreign direct investment enterprises is supported and Hypothesis 2 that foreign direct investment enterprises have a relationship to transfer pricing activities is supported. These results will lead to discussion and recommendations in the next parts of this paper.

\section{Discussion and empirical results}

The obtained empirical results are similar to previous studies, support the conceptual framework that the author proposes. In this study, corporate tax rate differentials are found to have a strong relationship with transfer pricing activities of foreign direct investment enterprises. Fig. 2 below illustrates the relationship between factors and items after SEM is conducted:

\begin{tabular}{|c|c|c|c|c|}
\hline $\begin{array}{l}\text { Corporate Tax } \\
\text { Rate Differentials }\end{array}$ & 0.747 & $\begin{array}{c}\text { Foreign direct } \\
\text { investment enterprises }\end{array}$ & 0.502 & $\begin{array}{c}\text { Transfer Pricing } \\
\text { Activities }\end{array}$ \\
\hline
\end{tabular}

Fig. 2. Model estimation result

As seen from the empirical results, Hypothesis 1 revealed that the corporate tax rate differentials had positive and significant effects on foreign direct investment enterprises with the coefficient is estimated at 0.747 , justified the benchmark of more than 0.2. The p-value is less than 0.001 . Therefore, in this research, this hypothesis is supported. In the same way, Hypothesis 2 shows that foreign direct investment enterprises positively and significantly affected the transfer pricing activities with the coefficient was estimated at 0.502 , higher than $0.2(\mathrm{P}<0.001)$. Therefore, in this research, the hypothesis is accepted. These results show how corporate tax rate differentials have effects on foreign direct investment enterprises, and then foreign direct investment enterprises also have effects on transfer pricing activities. This finding contributes to the understanding in transfer pricing activities of foreign direct investment enterprises in Vietnam, go along with the activities that the General Department of Taxation of Vietnam is carried out under the direction of the General Department of Taxation of Vietnam. The policymakers, lawmakers and economists when looking at the transfer pricing activities of foreign direct investment enterprises in Vietnam, upon this result, can pay more attention to the corporate tax rate differentials between Vietnam and other countries to have appropriate policies. The results in previous studies including the researches of Liu, Li, Tim, and Guo (2017), Nguyen and Duong (2018), Duong (2018), have shown the significance of tax rate differentials among countries in transfer pricing activities of foreign direct investment enterprises. Liu, Li, Tim, and Guo (2017) have suggested that enterprises often have transfer mispricing to transfer the profits from a higher-taxed country to a lower-taxed country. They also assumed that transfer pricing manipulation for tax motivation is popular in countries with low-to-medium-level corporate tax rates. Nevertheless, the literature review showed the impact of corporate tax rate differential among countries on the transfer pricing activities of foreign direct investment enterprises. The main issue identified during the setting of this research with regards to the tax rate gap was the impact of tax rate gap among countries on transfer pricing activities in FDI enterprises. A few questions regarding respondents' perception about whether tax rate gap between Vietnam and other countries is among priorities in investment decision of investors, Vietnam tax rate can change the company's approach to TP activities, corporate income tax incentive affects TP activities, "tax haven" countries have an impact on TP activities of FDI enterprises, transfer pricing activities among related parties can help reduce total global tax liability. According to Table 8, there is an adequate relationship between the corporate Tax rate differential and Transfer pricing activities. It was further concluded that the regression weight for Transfer pricing activities in foreign direct investment enterprises is significant. Therefore, the hypothesis is proven valid. Table 8 describes the relationship between corporate Tax rate differential and Transfer pricing activities. Therefore, this study describes that corporate Tax rate differential has a significant favourable influence on transfer pricing activities of foreign direct investment enterprises in Vietnam. The above findings are supported by the findings of Liu, Li, Tim, and Guo (2017), Duong (2018), Nguyen and Duong (2018). It is concluded that the corporate Tax rate differential plays an essential role in transfer pricing activities of foreign direct investment enterprises. In this study, the respondents agree with the statement that the respondents agree that the corporate tax rate differential impact on transfer pricing activities in FDI enterprises. In term of Corporate tax rate differentials, it is concluded that the respondents agree with the statement that: the same corporate income tax among countries will minimize transfer pricing manipulation of enterprises; Vietnamese corporate income tax rate that the company has to pay annually is high for the company, and corporate income tax incentive has an effect on TP activities. Otherwise, they are neither agreeing nor disagreeing with the statements that transfer pricing activities among related parties can help reduce total global tax liability. This research also shows that the respondents agree with all the statement that transfer pricing activities are carried out to maximize the profits; transfer pricing matters are discussed in board meetings of FDI enterprises very frequently, and transfer pricing is often required by parent companies from foreign countries. The result gained from the research indicates that respondents are neither agreeing nor disagreeing with all the statements TP activities among related parties of FDI enterprise can increase global consistency of approach, and TP activities among associated partners are a method that FDI enterprises use 
to operate its business. The respondents agree with the statement that: the corporate tax rate of different countries affect the transfer pricing activities among these countries.

\section{Conclusions and Recommendations}

Transfer pricing has been getting its attention in many areas, especially in the field of tax and economics as enterprises expand their businesses across countries, where the gap in tax rates among these economies may arise. To partly contribute to a better understanding of TP, the research aims to identify the relationship between corporate tax rate differentials and TP activities of FDI enterprises in Vietnam. The theoretical and empirical review has been made related to the issues. From the literature review, the author has shown how transfer price and transfer pricing are defined in international and Vietnamese researches. The definition of foreign direct investment enterprises is also examined in the term of Organization for Economic and Cooperation Development and under the Investment Law of Vietnam. Also, from the literature review, the author sees that former researchers found the relationship between the corporate tax rate differentials among countries and the transfer pricing activities of the foreign direct investment enterprises. With the rising issue of transfer pricing in Vietnam, the author sees the need to continue study on TP, supplement and renew theory to catch up with globalization in the current context of TP management and control. The research methodology is examined in session three. Research onion is, and it requires the choices of research philosophy, research approach, research strategy, research method, time horizon, and data collection. After the discussions, the researcher applies positivism research philosophy and deductive research approach. Moreover, the survey is chosen as a research strategy and primary data, therefore, is collected from a self-administered questionnaire. The researcher relies on Survey Monkey, which is known as an online survey tool to implement the survey. Secondary data is also collected from published statistics and reports, and the role of this data is visible in literature. 150 respondents from FDI enterprises in Vietnam have given feedback on questionnaires. The empirical result shows that corporate tax rate differentials are found to have a strong relationship with transfer pricing activities of foreign direct investment enterprises. The author finds acceptable internal consistency reliability of the research, model testing, EFA analysis and hypothesis testing accepted with Hypothesis 1 and Hypothesis 2, which is similar to the literature review. Therefore, based on this result, the author suggests further research on the relationship between corporate tax rate differentials and transfer pricing activities of FDI enterprises in Vietnam to be conducted with the official survey of 379 respondents as suggested in Methodology. With the above empirical analysis, the author recognizes the limitation of the study as the findings may be correct only for the sample, not for the whole population. However, further research in terms of the effect that corporate tax rate differentials pose on TP activities of FDI enterprises can be carried out upon this conceptual study framework. These further researches can give recommendations for better tax rate in Vietnam and can help much in suggesting a better solution to TP abuse. To further study the tax rate gap among Vietnam and other countries to have better solutions with transfer pricing manipulation. This suggestion was supported as the results of the findings in the study of Liu, Li, Tim, and Guo (2017) as they discovered in their study that transfer mispricing with tax motivation is popular in countries that are not tax havens and have low-to-medium-level corporate tax rates. With the above-chosen research methodology components, the researcher recognizes several limitations of the study. Firstly, the paper findings are based on limited sample size. Even the sample size is acceptable for academic studies provided by previous researchers; the author is aware of expected findings may be correct for this sample only and may not be correct for the whole population. Secondly, the limitation may come from the chosen self-administered questionnaire as this kind of survey's weakness is that the answers of the respondents are not verified, and the respondents may provide the feedback that does not reflect their real thinking.

\section{References}

Agarwal, S. (2016). Transfer Pricing Meaning Examples Risks Benefits. Available at: https://www.linkedin.com/pulse/transferpricing-meaning-examples-risks-benefits-shivangi-agarwal (accessed 10 Aug 2018)

Akpojevwa, O. A. (2014). The effects of international transfer pricing on host nations: An overview of developing nations. SCSR Journal of Business and Entrepreneurship (SCSR-JBE), 1(1), $34-41$

Armat, M. R., Assarroudi, A., Rad, M., Sharifi, H., \& Heydari, A. (2018). Inductive and deductive: Ambiguous labels in qualitative content analysis. The Qualitative Report, 23(1), 219-221.

Biggam, J. (2015). Succeeding with your master's dissertation: a step-by-step handbook. McGraw-Hill Education (UK).

Bilau, A. A., Witt, E., \& Lill, I. (2015). A framework for managing post-disaster housing reconstruction. Procedia Economics and Finance, 21(15), 313-320.

Borkowaki, S.C. (1997b). The transfer pricing concerns of developed and developing countries. International Journal of Accounting, 32(3), 321-36.

Cohen, J. (1969). Statistical power analysis for the behavioral sciences. CA: Academic Press, San Diego.

Deloitte, (2016). Trends in Transfer Pricing. Retrieved from https://www2.deloitte.com/content/dam/Deloitte/global/Documents/Tax/dttl-tax-transfer-pricing-global-research-bulletin.pdf on 28th December 2018.

Dillman, D. A., Smyth, J. D., \& Christian, L. M. (2014). Internet, phone, mail, and mixed-mode surveys: the tailored design method. John Wiley \& Sons. 
Do, D. Q. (2014). Transfer pricing under the view of enterprises. Retrieved from: http://tapchitaichinh.vn/nghien-cuu--trao-doi/traodoi-binh-luan/chuyen-gia-duoi-goc-nhin-cua-doanh-nghiep-53143.html on 15th Jan 2019.

Duong, T.V.A. (2018), "Current situation of transfer pricing and anti transfer pricing methods toward FDI enterprises in Vietnam", Magazine of Accounting and Auditing, April 2018, available at: http://vaa.net.vn/Tin-tuc/Tin-chi-tiet/newsid/4321/Thuc-trangchuyen-gia-va-giai-phap-chong-chuyen-gia-doi-voi-cac-doanh-nghiep-co-von-dau-tu-nuoc-ngoai-FDI-tai-Viet-Nam (accessed 15 Mar 2019)

Easterby-Smith, M., Thorpe, R., \& Jackson, P. R. (2015). Management and business research. Sage.

Eden, L. (1998). Taxing Multinationals: Transfer Pricing and Corporate Income Taxation in North America. Toronto: University of Toronto Press. 757 pp.

Etikan, I., \& Bala, K. (2017). Sampling and sampling methods. Biometrics \& Biostatistics International Journal, $5(6), 00149$.

Halperin, R., \& Srinidhi, B. (1987). The effects of the US income tax regulations' transfer pricing rules on allocative efficiency. Accounting Review, 62, 686-706.

Hanlon, B., \& Larget, B. (2011). Samples and Populations. Department of Statistics University of Wisconsin-Madison.

Horst, T. (1971). The theory of the multinational firm: Optimal behavior under different tariff and tax rates. Journal of Political Economy, 79(5), 1059-72.

Hung, L. (2017). What is best solution to FDI with transfer pricing activities?. Available at http://vietnamfinance.vn/loi-giai-nao-hoply-voi-doanh-nghiep-fdi-chuyen-gia-20171226115216343.htm (accessed 27 Jul 2018).

Krejcie, R. V., \& Morgan, D. W. (1970). Determining sample size for research activities. Educational and psychological measurement, 30(3), 607-610.

Lall, S. (1973). Transfer pricing by multinational manufacturing firms. Oxford Bulletin of Economics and Statistics, 53(3).

Lecraw, D. (1985). Some evidence on transfer pricing Multinational Corporations. Edited by Alan Rugman and Lorraine Eden, Croom Helm London, p. 223-240.

Liu, L., Schmidt-Eisenlohr, T., \& Guo, D. (2017). International transfer pricing and tax avoidance: Evidence from linked trade-tax statistics in the UK. Review of Economics and Statistics, 1-45.

Memon, M. A., Ting, H., Ramayah, T., Chuah, F., and J.H. Cheah, 2017. A review of the methodological misconceptions and guidelines related to the application of structural equation modeling: A Malaysian scenario. Journal of Applied Structural Equation Modeling, 1(1), 1-13.

Ministry of Planning and Investment (2018). Statistics on Foreign Direct Investment in Vietnam 2018. Official Statistics.

Nguyen, H., Tham, J., Khatibi, A., \& Azam, S. (2019). Enhancing the capacity of tax authorities and its impact on transfer pricing activities of FDI en-terprises in Ha Noi, Ho Chi Minh, Dong Nai, and Binh Duong province of Vietnam. Management Science Letters, 9(8), 1299-1310.

Nguyen, H., Tham, J., Khatibi, A \& Azam, S. (2020). Conceptualizing the effects of transfer pricing law on transfer pricing decision making of FDI enterprises in Vietnam. International Journal of Data and Network Science, 4(2). DOI: 10.5267/j.ijdns.2020.1.002

Nguyen, N. Q. (2018). What should be done to prevent transfer pricing in FDI enterprises in Vietnam. Retrieved from https://doanhnhanviet.net.vn/y-kien/can-lam-gi-de-chong-chuyen-nhuong-gia-cua-cac-doanh-nghiep-fdi-tai-viet-nam-1580.html

Organisation for Economic Cooperation and Development (2010). OECD Transfer Pricing Guidelines for Multinational Enterprises and Tax Administrations 2010. OECD Publishing, Paris. Available at: https://doi.org/10.1787/tpg-2010-en.

Saunders, M., Lewis, P., \& Thornhill, A. (2016). Research methods for business students. Pearson Education Limited, Harlow.

Sekaran, U., \& Bougie, R. (2013). Research Methods for Business: A Skill-Building Approach. $6^{\text {th }}$ ed., Wiley, New York.

Thang, N.D. (2015). Experience in controlling transfer pricing in some countries, lessons for Vietnam. Available at: http://tapchitaichinh.vn/nghien-cuu--trao-doi/trao-doi-binh-luan/kiem-soat-hoat-dong-chuyen-gia-cua-mot-so-nuoc-va-bai-hoccho-viet-nam-71314.html. (accessed 15 Oct 2018).

Thu, L. (2018). Almost 50\% FDI enterprises report of loss. Available at http://baochinhphu.vn/30-nam-dau-tu-nuoc-ngoai-tai-VietNam/Gan-50-doanh-nghiep-FDI-bao-lo-Ke-ho-chuyen-gia/341155.vgp (accessed 29 Aug 2018).

Vietnamese Government (2017). Decree no. 20/2017/ND-CP of the Government dated 24 Feb 2017, effectively from 1 May 2017, on providing tax administration applicable to enterprises engaging in controlled transactions.

Vietnamese Ministry of Finance (2017). Circular no. 41/2017/TT-BTC of the Ministry of Finance of the Government dated 28 Apr 2017, on guiding the implementation of a number of articles of the Government's Decree No. 20/2017/ND-CP of the Government dated 24 Feb 2017 on providing tax administration applicable to enterprises engaging in controlled transactions.

Vietnamese National Assembly (2014). Investment Law dated 26 Nov 2014, effective from 1 Jul 2015.

Wadgave, U., \& Khairnar, M. R. (2016). Parametric tests for Likert scale: For and against. Asian journal of psychiatry, $24,67$.

Walliman, N. (2017). Research Methods: The Basics. 2nd Edition, Routledge.

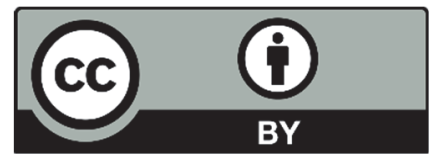

(C) 2020 by the authors; licensee Growing Science, Canada. This is an open access article distributed under the terms and conditions of the Creative Commons Attribution (CC-BY) license (http://creativecommons.org/licenses/by/4.0/). 